\title{
Interleukin-18 Involvement in Hypoxic-Ischemic Brain Injury
}

\author{
Maj Hedtjärn, ${ }^{1}$ Anna-Lena Leverin, ${ }^{1}$ Kristina Eriksson, ${ }^{2}$ Klas Blomgren, ${ }^{1,3}$ Carina Mallard, ${ }^{1}$ and \\ Henrik Hagberg ${ }^{1,4}$
}

Departments of ${ }^{1}$ Physiology and Pharmacology, ${ }^{2}$ Medical Microbiology and Immunology, ${ }^{3}$ Pediatrics, and ${ }^{4}$ Obstetrics and Gynecology, Perinatal Center, Göteborg University, 40530 Göteborg, Sweden

Inflammation is a critical factor for development of hypoxicischemic (HI) brain injury. Interleukin-18 (IL-18) is a proinflammatory cytokine expressed in microglia and processed by caspase-1. Our aim was to characterize the expression of IL-18 and its receptor in relation to caspase- 1 and IL-1 $\beta$ after $\mathrm{HI}$ and to evaluate to what extent IL-18 contributes to HI brain injury. Seven-day-old rats were subjected to $\mathrm{HI}$, and brain tissue was sampled at different time points ( $3 \mathrm{hr}$ to $14 \mathrm{~d}$ ) after insult. The mRNA for IL-18 and caspase- 1 were analyzed with reverse transcriptase PCR, protein was analyzed by Western blot (IL18, caspase-1) or ELISA (IL-1 $\beta$ ), and the regional distribution was assessed by immunohistochemistry. $\mathrm{HI}$ was also induced in C57BL/6 mice, and brain injury in IL-18-deficient animals was compared with that in wild-type animals. The expression of mRNA/protein for caspase-1 and IL-18 in brain homogenates increased progressively at $12 \mathrm{hr}$ to $14 \mathrm{~d}$ after $\mathrm{HI}$, whereas IL-1 $\beta$ peaked at $8 \mathrm{hr}$. A widespread expression of caspase-1 and IL-18 protein in microglia was found in the $\mathrm{HI}$ hemisphere. The IL-18 receptor was expressed on neurons of the cerebral cortex and thalamus. IL-1 $\beta$ was primarily found in microglia in the habenular nucleus of the thalamus. The infarct volume was reduced by $21 \%$ ( $p=0.01)$, and the neuropathology score was significantly decreased in the cerebral cortex $(-35 \%)$, hippocampus $(-22 \%)$, striatum $(-18 \%)$, and thalamus $(-17 \%)$ in mice with IL-18 deficiency compared with wild-type mice. In conclusion, we found that IL-18 expression in microglia was markedly increased after $\mathrm{HI}$ and that IL-18 appears to be important for the development of $\mathrm{HI}$ brain injury.

Key words: IL-18; caspase-1; IL-1 $\beta$; neonatal; inflammation; microglia
Recent clinical and experimental evidence indicates that inflammatory mediators, including proinflammatory cytokines, play an important role in the pathogenesis of perinatal hypoxic-ischemic (HI) brain injury (Hagberg et al., 1996; Silverstein et al., 1997; Yoon et al., 1997; Bona et al., 1999). Interleukin-1 $\beta$ (IL-1 $\beta$ ) converting enzyme (caspase-1) is a cysteine protease that is responsible for the maturation of the proinflammatory cytokines IL- $1 \beta$ and IL-18. Both IL- $1 \beta$ and IL-18 are synthesized as inactive precursors that require cleavage by caspase- 1 to become fully bioactive. Several findings imply that caspase-1 has an important role in mediating brain injury after ischemia. Caspase-1 mRNA and protein were upregulated after cerebral ischemia in adult gerbils (Bhat et al., 1996), and intracerebroventricular administration of the caspase-1 inhibitor Ac-YVAD-cmk has been shown to reduce brain injury after ischemia in the adult mouse (Hara et al., 1997) and rat (Rabuffetti et al., 2000). In the neonatal brain, caspase-1 seems to be an important mediator of brain injury, because caspase-1-deficient mice are resistant to neonatal HI brain damage (Liu et al., 1999). Because mice deficient in caspase- 1 have neither mature IL- $1 \beta$ nor IL-18 (Wang and Lenardo, 2000), it is possible that both these proinflammatory cytokines are involved in the development of brain injury. Brain damage is increased after intracerebroventricular injection of

Received Dec. 28, 2001; revised April 2, 2002; accepted April 24, 2002.

This work was supported by the Swedish Foundation for Strategic Research (27-1-99) and by the Swedish Medical Research Council (09455), the Åhlén Foundation, the Sven Jerring Foundation, the Magnus Bergvall Foundation, the Wilhelm and Martina Lundgren Foundation, the Linnéa and Josef Carlsson Foundation, the Frimurare Barnhus Foundation, and the Åke Wibergs Foundation.

Correspondence should be addressed to Maj Hedtjärn, Department of Physiology, Box 432, Göteborg University, 40530 Göteborg, Sweden. E-mail: maj.hedtjarn@fysiologi.gu.se.

Copyright (C) 2002 Society for Neuroscience $0270-6474 / 02 / 220001-10 \$ 15.00 / 0$
IL-1 $\beta$ in adult rats subjected to stroke (Yamasaki et al., 1995; Stroemer and Rothwell, 1998), whereas intracerebroventricular administration of IL-1 receptor antagonist significantly decreases ischemic brain damage (Relton and Rothwell, 1992; Loddick and Rothwell, 1996; Stroemer and Rothwell, 1997). In the neonatal brain, we and others have shown previously that the mRNA levels of IL- $1 \beta$ and the bioactivity of IL- 1 are increased after HI, and that intracerebroventricular administration of IL-1 receptor antagonist significantly reduces brain injury after HI (Martin et al., 1994; Szaflarski et al., 1995; Hagberg et al., 1996).

IL-18 is a newly discovered proinflammatory cytokine, originally identified as interferon- $\gamma$ (IFN- $\gamma$ )-inducing factor (Okamura et al., 1995). IL-18 is related to IL- $1 \beta$ more than to any other cytokine. The cytokines are similar in terms of structure, processing, receptor complex, signal transduction pathway, and proinflammatory properties (Dinarello, 1999; Lebel-Binay et al., 2000). IL-18 and IL-18 receptor (IL-18R) mRNA have been detected in brain tissue from adult rats (Culhane et al., 1998; Wildbaum et al., 1998), and cultures of murine microglia have been shown to both produce and respond to IL-18 (Conti et al., 1999; Prinz and Hanisch, 1999). Recently, IL-18 deficiency in mice was associated with impaired microglia response in connection with experimental viral infection (Mori et al., 2001), implying that IL-18 is critical for activation of CNS microglia. Because previous data suggest that excessive microglia activation exerts toxic effects after HI (McRae et al., 1995; Yrjanheikki et al., 1999; Galasso et al., 2000), we hypothesized that IL-18 may be involved in the injurious processes in the brain after $\mathrm{HI}$.

Our aim was to first characterize the gene and protein expression and immunolocalization of IL-18, IL-18R, caspase-1, and IL- $1 \beta$ after $\mathrm{HI}$ in the neonatal rat brain. Second, the involvement 
of IL-18 in brain injury was evaluated by assessment of the extent of brain damage in IL-18-deficient and wild-type neonatal mice subjected to HI.

\section{MATERIALS AND METHODS}

\section{Induction of $\mathrm{HI}$ in neonatal rats}

Neonatal HI was induced in rats at postnatal day 7 (P7) according to the methods presented by Rice et al. (1981), with some modifications. Outbred Wistar rats (Moellegaard Breeding and Research Centre A/S, Skensved, Denmark) of either sex were anesthetized with enflurane (3\% for induction and $1.5 \%$ for maintenance) in nitrous oxide/oxygen (1:1). The left common carotid artery was dissected and cut between ligatures of prolene suture (6.0). After the surgical procedure, the wounds were closed and infiltrated with a local anesthetic and the pups were allowed to recover for 1-2 hr. The litters were then placed in a chamber perfused with a humidified gas mixture $(7.7 \%$ oxygen in nitrogen) for $60 \mathrm{~min}$ at $36^{\circ} \mathrm{C}$. The animals were kept in humidified air at $36^{\circ} \mathrm{C}$ for $10 \mathrm{~min}$ before and 10 min after hypoxic exposure. The pups were returned to their dams after the hypoxic exposure. This procedure results in brain injury in the ipsilateral hemisphere, consisting of cerebral infarction in the cortex, striatum, hippocampus, and thalamus as described previously (Bona et al., 1998). Control littermates were neither operated on nor subjected to hypoxia. All animal experiments were approved by the local Ethical Committee of Göteborg (no. 183/99).

\section{Induction of $\mathrm{HI}$ in neonatal mice}

C57BL/6 wild-type mice (obtained from Moellegaard Breeding and Research Centre A/S) and C57BL/6 mice lacking the gene for IL-18 (Takeda et al., 1998) were bred at Experimental Biomedicine (Göteborg University, Göteborg, Sweden). At P9, mice of either sex were subjected to neonatal $\mathrm{HI}\left(10 \%\right.$ oxygen in nitrogen for $60 \mathrm{~min}$ at $\left.36^{\circ} \mathrm{C}\right)$. The animal experiments were approved by the local Ethical Committee of Göteborg (no. 269/01).

\section{Western blot}

Pups were deeply anesthetized by intraperitoneal injection of $150 \mu \mathrm{l}$ of thiopental $(50 \mathrm{mg} / \mathrm{ml})$ and were perfused intracardially with $0.9 \% \mathrm{NaCl}$ at $3 \mathrm{hr}, 8 \mathrm{hr}, 14 \mathrm{hr}, 1 \mathrm{~d}, 3 \mathrm{~d}, 6 \mathrm{~d}$, and $14 \mathrm{~d}$ after HI; control animals were perfused at P7, P8, P10, P13, and P21 ( $n=6$ at each time point). The brains were rapidly dissected out and quickly frozen. Each hemisphere was homogenized in ice-cold homogenization buffer (50 mM Tris, $\mathrm{pH} 7.3$, containing 5 mm EDTA). Protease inhibitor cocktail (P8340; Sigma, St. Louis, MO) was added to a final concentration of $1 \%$. The protein concentration was determined according to the method presented by Whitaker and Granum (1980) adapted for microplates. Homogenate samples were mixed with an equal volume of $3 \times$ SDS-PAGE buffer and heated $\left(96^{\circ} \mathrm{C}\right)$ for $5 \mathrm{~min}$. Samples were electrophoresed on Novex (San Diego, CA) precast $8-16 \%$ or $10-20 \%$ Tris-glycine gels. All samples were transferred to reinforced nitrocellulose (Optitran, $0.2 \mu \mathrm{m}$; Schleicher \& Schuell, Dassel, Germany) membranes. Membranes were blocked in $30 \mathrm{~mm}$ Tris- $\mathrm{HCl}$, pH 7.5, $100 \mathrm{~mm} \mathrm{NaCl}$, and $0.1 \%$ Tween 20 (TBS-T) containing $5 \%$ fat-free milk powder. The following primary antibodies, dilutions (diluted in TBS-T containing 3\% BSA and $9 \mathrm{~mm} \mathrm{NaN}_{3}$ ), and incubation times were used: rabbit anti-caspase-1 (1:200, $1 \mathrm{hr}$ at room temperature, M-20; Santa Cruz Biotechnology, Santa Cruz, CA), monoclonal mouse anti- $\alpha$-tubulin $(1: 1000,1 \mathrm{hr}$ at room temperature, MON 4009; Cedarlane, Hornby, Ontario, Canada), and goat anti-IL-18 (1:100, $4^{\circ} \mathrm{C}$ overnight, AF521; R \& D Systems, Minneapolis, MN). After washing, membranes were incubated with the appropriate peroxidaseconjugated secondary antibodies (Vector Laboratories, Burlingame, CA) diluted in blocking buffer. Immunoreactive species were visualized using Super Signal Western Dura chemiluminescence substrates (Pierce, Rockford, IL) and a cooled CCD camera (LAS1000; Fujifilm, Tokyo, Japan). Immunoreactive bands were quantified using Image Gauge software (version 3.3; Fujifilm). Every sample was analyzed three times, and the average value was used as $n=1$. Stripping of membranes for reprobing purposes was performed by incubation in $62.5 \mathrm{~mm}$ Tris- $\mathrm{HCl}$, $\mathrm{pH}$ 6.7, $100 \mathrm{~mm} \beta$-mercaptoethanol, and $2 \% \mathrm{SDS}$ at $50^{\circ} \mathrm{C}$ for $30 \mathrm{~min}$.

\section{Immunohistochemistry}

Pups were deeply anesthetized by intraperitoneal injection of $150 \mu \mathrm{l}$ of thiopental $(50 \mathrm{mg} / \mathrm{ml})$ and were perfused intracardially with $0.9 \% \mathrm{NaCl}$ and then $5 \%$ buffered formaldehyde (Histofix; Histolab, Göteborg, Swe- den) at $3 \mathrm{hr}, 8 \mathrm{hr}, 12 \mathrm{hr}, 24 \mathrm{hr}, 3 \mathrm{~d}, 6 \mathrm{~d}$, and $14 \mathrm{~d}$ after $\mathrm{HI}(n=6$ at each time point). The brains were rapidly removed, immersion-fixed at $4^{\circ} \mathrm{C}$ for $24 \mathrm{hr}$, dehydrated, embedded in paraffin, and cut into 5- $\mu \mathrm{m}$-thick coronal sections. Control pups were killed at P7, P8, P10, P13, and P21 $(n=3)$, and the brains were prepared as described above. The following primary antibodies, dilutions, and incubation times were used: rabbit anticaspase-1 (1:200 in PBS, $1 \mathrm{hr}$ at room temperature, M-20; Santa Cruz Biotechnology), goat anti-IL-18 (1:100 in PBS containing $0.2 \%$ Triton $\mathrm{X}-100$ and $0.1 \%$ BSA, overnight at $4{ }^{\circ} \mathrm{C}, \mathrm{M}-19$; Santa Cruz Biotechnology), sheep anti-IL-1 $\beta$ (1:400 in PBS containing $0.2 \%$ Triton X-100 and $0.1 \%$ BSA, overnight at $4^{\circ} \mathrm{C}, \mathrm{S} 328 / \mathrm{B} 4 \mathrm{~b}$; National Institute for Biological Standards and Control, Herts, UK), goat anti-mouse IL-18R $(2 \mu \mathrm{g} / \mathrm{ml}$ in PBS containing $0.2 \%$ Triton X-100, $1 \mathrm{hr}$ at room temperature, AF856; R \& D Systems), and mouse anti-neuronal-specific nuclear protein (NeuN) $(4 \mu \mathrm{g} / \mathrm{ml}$ in PBS, $1 \mathrm{hr}$ at room temperature; Chemicon, Temecula, CA). Before immunohistochemical staining, sections were deparaffinized and boiled in citric acid buffer $(0.01 \mathrm{M}, \mathrm{pH} 6.0,10 \mathrm{~min})$. For caspase- 1 and IL-18R staining, sections were also treated with proteinase $\mathrm{K}(10 \mu \mathrm{g} / \mathrm{ml}$ in PBS, 9 min; Boehringer Mannheim, Mannheim, Germany). Nonspecific binding was blocked by incubation with appropriate serum (10\%). After incubation with primary antibodies, sections were washed in PBS and incubated with biotinylated secondary antibodies (Vector Laboratories) for $1 \mathrm{hr}$, followed by inhibition of endogenous peroxidase $(0.6 \%$ $\mathrm{H}_{2} \mathrm{O}_{2}$ in methanol, $10 \mathrm{~min}$ ) and incubation with avidin-biotin enzyme complex $(20 \mu \mathrm{l} / \mathrm{ml}, 1 \mathrm{hr}, \mathrm{ABC}$-Elite; Vector Laboratories). Immunoreactivity was visualized using DAB $(0.5 \mathrm{mg} / \mathrm{ml})$ enhanced with nickel sulfate $(15 \mathrm{mg} / \mathrm{ml})$ (Gilland et al., 1998). For double-labeling experiments, FITC-streptavidin $(10 \mu \mathrm{g} / \mathrm{ml}$ in PBS) or Texas Red-conjugated avidin D $(25 \mu \mathrm{g} / \mathrm{ml}$ in PBS) was used after incubation with biotinylated secondary antibody; alternatively, secondary antibodies directly conjugated to Texas Red or FITC were used. Microglia were detected using FITC-labeled isolectin $\mathrm{B}_{4}(10 \mu \mathrm{g} / \mathrm{ml}$ in PBS, $1 \mathrm{hr}$, L-2895; Sigma).

The specificity of antibodies was tested by omission of the primary antibody and by preabsorption of primary antibodies with an excess $(10 \times$ and $100 \times$ ) blocking peptide for caspase-1 and IL-18 (sc-515 P and sc-6179 P; Santa Cruz Biotechnology) and with an excess $(50 \times)$ recombinant rat IL-1 $\beta$ (501-RL; R \& D Systems) for IL-1 $\beta$.

\section{ELISA}

$I L-1 \beta$. Brain tissue was prepared as described under Western blotting procedures. After homogenization, protease inhibitor cocktail (P8340; Sigma) was added to a final concentration of $5 \%$. The homogenates were centrifuged at $10,000 \times g$ at $4^{\circ} \mathrm{C}$ for $10 \mathrm{~min}$. The supernatants were collected and used for the ELISA. For the assay, a rat IL-1 $\beta$ immunoassay kit, Quantikine M (RLB00; R \& D Systems), was used. Every sample was assayed in duplicate. The standard was diluted in homogenization buffer with 5\% protease inhibitor cocktail. Apart from this, the assay was performed as recommended by the manufacturer.

$I L-18$. C57BL/6 wild-type mice were killed at $3 \mathrm{~d}(n=8)$ and $6 \mathrm{~d}(n=$ 7) after HI; control animals were killed at P12 $(n=3)$. Brain tissue was prepared and centrifuged as described above. For the assay, a mouse IL-18 ELISA kit (7625; R \& D Systems) that reacts with the active form of IL-18 was used. The two monoclonal antibodies used in this assay were raised against recombinant mouse IL-18, which represents the mature and active form of IL-18 (corresponding to amino acids 36-192). Every sample was assayed in duplicate, and the assay was performed as recommended by the manufacturer.

\section{Reverse transcriptase- $P C R$}

The pups were killed at $3 \mathrm{hr}, 6 \mathrm{hr}, 12 \mathrm{hr}, 1 \mathrm{~d}, 3 \mathrm{~d}, 6 \mathrm{~d}$, and $14 \mathrm{~d}$ after HI, and the brains were rapidly removed and frozen in liquid nitrogen. Control animals were killed on P7, P8, P10, P13, and P21, respectively. Total RNA was extracted from each hemisphere using the guanidine isothiocyanate-cesium chloride method (Chirgwin et al., 1979). The RNA was quantified by spectrophotometry at $260 \mathrm{~nm}$ and stored at $-80^{\circ} \mathrm{C}$. First-strand cDNA synthesis was performed with a Superscript RNase $\mathrm{H}^{-}$reverse transcriptase kit (Invitrogen, San Diego, CA), random hexamer primers, and deoxyNTP (dNTP) (dATP, dCTP, dGTP and dTTP; Roche Molecular Biochemicals, Indianapolis, IN), as described previously (Blomgren et al., 1999).

Each PCR $(25 \mu \mathrm{l})$ contained 1/25 of the cDNA synthesis reaction, $0.2 \mathrm{~mm}$ dNTP, $2.5 \mu$ l of $10 \times$ PCR buffer (in mM: 250 Tris- $\mathrm{HCl}, \mathrm{pH} 8.3,375 \mathrm{KCl}$, $15 \mathrm{MgCl}_{2}$; Sigma), $1 \mathrm{U}$ of Taq DNA polymerase (Sigma), and $1 \mu \mathrm{M}$ upstream (U) and downstream (D) primers [caspase-1 U, 5'-CCAGAGCACAAGACTTCTGAC; caspase-1 D, 5'-TGGTGTTGAAGAGCA- 
GAAAGC; GenBank accession no. U14647; glyceraldehyde-3-phosphate dehydrogenase (GAPDH) U, 5'-ACCACCATGGAGAAGGCTGG; GAPDH D, 5'-CTCAGTGTAGCCCAGGATGC; GenBank accession no. M17701A; IL-18 U, 5'-TGGAGACTTGGAATCAGACC; IL-18 D, 5'GGCAAGCTAGAAAGTGTCCT; GenBank accession no. AJ222813]. Primers were from CyberGene AB (Huddinge, Sweden). The annealing temperature was $60^{\circ} \mathrm{C}$ for caspase- 1 and GAPDH and $58^{\circ} \mathrm{C}$ for IL-18. The cycle numbers ( 30 cycles for caspase-1, 20 cycles for GAPDH, and 29 cycles for IL-18) were chosen such that the PCR product would be in the linear phase of amplification.

The PCR products were separated on a $1.5 \%$ agarose $/ 0.5 \times$ Tris borate EDTA gel containing ethidium bromide. A $100 \mathrm{bp}$ ladder was used to verify the size of the PCR products. The gels were exposed in an LAS 1000 cooled CCD camera (Fujifilm), and bands were quantified using Image Gauge software (version 3.3; Fujifilm).

\section{Evaluation of brain injury in IL-18 knock-out and control mice}

Pups [IL-18 knock-out (IL-18 KO), $n=34$; wild-type mice, $n=21$ ] were killed on P12. Brains were perfusion-fixed with $5 \%$ paraformaldehyde, dehydrated, embedded in paraffin, and sectioned into 5- $\mu \mathrm{m}$-thick coronal sections at 10 evenly distributed anteroposterior levels from the anterior striatum to the posterior aspect of the hippocampus. Adjacent sections were stained with thionin/acid fuchsin (Mallard et al., 1993) and for microtubule-associated protein $(1: 1000,1 \mathrm{hr}$, mouse-anti-MAP-2, clone HM-2; Sigma). Immunoreactivity was visualized with DAB as described above.

Brain injury in different regions was evaluated by an observer blinded to the study groups, using a semiquantitative neuropathological scoring system modified from the system presented by Bona et al. (1998). Injury in the cerebral cortex was graded from 0 to 4 (with 0 being no observable injury and 4 being confluent infarction encompassing most of the hemisphere). The damage in the hippocampus, striatum, and thalamus was assessed regarding both hypotrophy (shrinkage) $(0-3)$ and observable cell injury/infarction (0-3), resulting in a neuropathological score for each brain region $(0-6)$. The total score $(0-22)$ was the sum score for all four regions.

Intact neurons (dendrites and soma) express MAP-2, and infarction in gray matter is associated with a distinct loss of MAP-2 immunoreactivity, which parallels the secondary loss of glucose metabolism in the tissue (Gilland et al., 1998). MAP-2-positive areas in the ipsilateral and contralateral hemispheres were outlined by an observer blinded to the study groups and were calculated using the Olympus Micro Image image analysis software, version 4.0 (Olympus Optical, Tokyo, Japan). The proportion of infarction was calculated by subtracting the MAP-2positive area of the ipsilateral hemisphere from the contralateral hemisphere and was expressed as a percentage of the contralateral hemisphere.

\section{Statistics}

The HI-induced changes in caspase- 1 and IL-18 mRNA and the changes in caspase- 1 , IL-18, and IL- $1 \beta$ protein in the ipsilateral hemispheres were compared with age-matched controls and contralateral hemispheres using the Mann-Whitney $U$ test (with Bonferroni correction when multiple comparisons were made). Expression of mRNA and protein during normal development (P7-P21) were compared using ANOVA (Newman-Keuls post hoc test). Brain injury in IL-18-deficient and wild-type mice was compared using the Mann-Whitney $U$ test. All data are expressed as mean \pm SEM.

\section{RESULTS}

\section{IL-18 mRNA and protein expression after HI}

Reverse transcriptase (RT)-PCR performed on mRNA from ipsilateral and contralateral hemispheres after HI and from controls produced a 398 bp IL-18 fragment (data not shown). The mRNA levels of IL-18 did not change significantly during normal development (P7, P8, P10, P13, and P21) (Fig. 1A). A significant threefold increase in IL-18 mRNA was observed at $1 \mathrm{~d}$ of reperfusion $(p=0.0065)$ in the ipsilateral hemisphere, compared with the mRNA levels in corresponding controls (Fig. 1A). The mRNA expression of IL-18 in the ipsilateral hemisphere increased further at $3 \mathrm{~d}(p=0.025)$ and continued to increase until
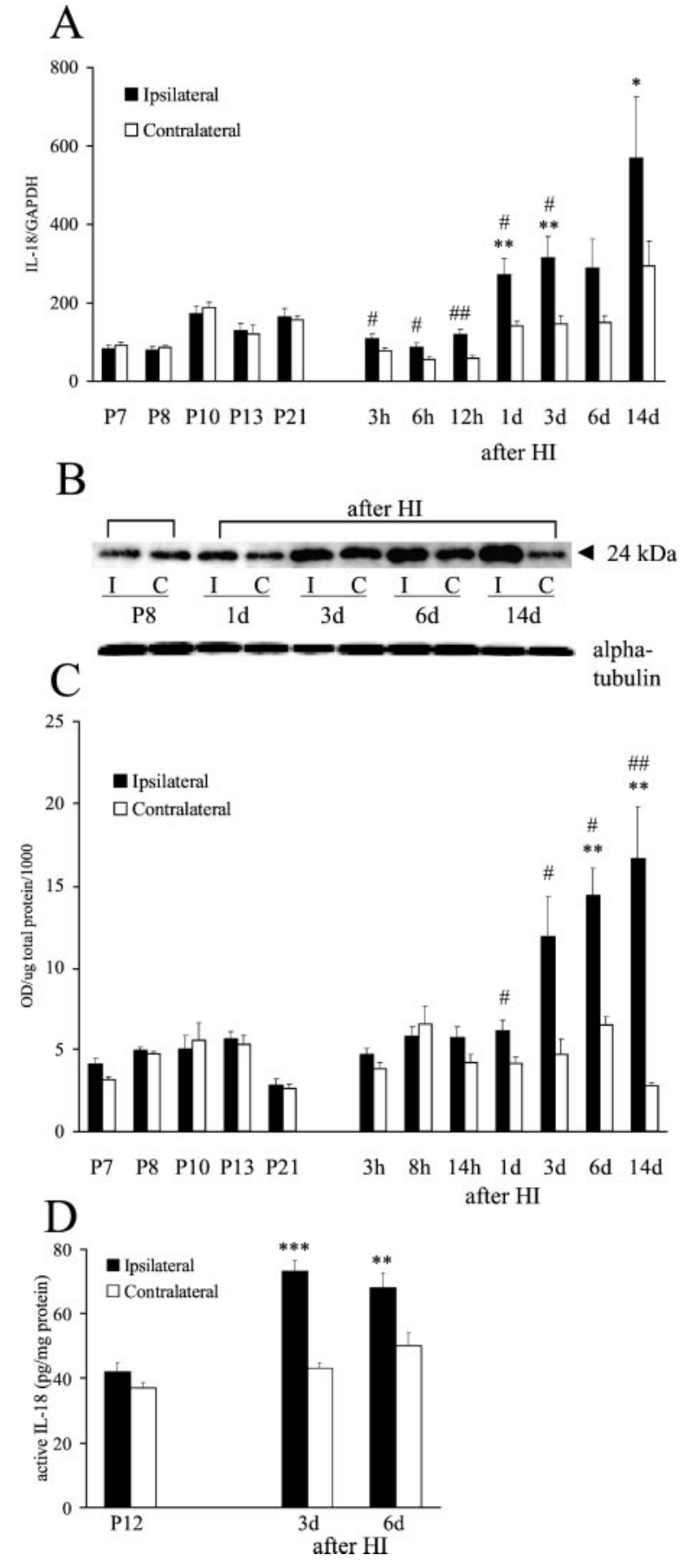

Figure 1. Expression of IL-18 mRNA $(A)$ and protein $(B-D)$ after HI. IL-18 mRNA levels are normalized against GAPDH mRNA, and the ratio of IL-18/GAPDH is shown in $A$. $B$, Individual samples on Western blot with detection of a $24 \mathrm{kDa}$ band. $\alpha$-Tubulin was used as control for equal loading. $I$ and $C$ indicate the ipsilateral and contralateral hemispheres, respectively, of the same animal at each time point. Samples are shown in control animals at P8 and at various times of recovery after $\mathrm{HI}(1,3,6$, and $14 \mathrm{~d})$. $C$, Expression of the $24 \mathrm{kDa}$ IL-18 protein from measured values. $O D$, Optical density. In $A$ and $C$, results are given for control animals at different postnatal ages (P7, P8, P10, P13, and P21) and at different time points of recovery after HI ( $n=6$ in each group). Data are expressed as mean \pm SEM. ${ }^{*} p<0.05 ; * p<0.01$ when compared with the corresponding hemispheres from control animals at the same postnatal day. ${ }^{\#} p<0.05$; ${ }_{\# \#}^{\#}<0.01$ when compared with contralateral hypoxic, undamaged hemispheres. $D$, Expression of active IL-18 at P12 and at 3 and $6 \mathrm{~d}$ after $\mathrm{HI}$ in wild-type mice. Data are expressed as mean $\pm \mathrm{SEM} ;{ }^{* *} p=0.01 ;{ }^{* * *} p<$ 0.001 when compared with contralateral hemispheres. 
at least $14 \mathrm{~d}$ of reperfusion, reaching a 3.5-fold increase compared with controls $(p=0.018)$ (Fig. $1 A)$. The mRNA levels in the contralateral hemispheres were significantly lower than those in the HI hemispheres $3 \mathrm{hr}$ to $3 \mathrm{~d}$ after insult (Fig. $1 A$ ).

The antibody against IL-18 displayed a distinct band on Western blots with an apparent molecular mass of $24 \mathrm{kDa}$, which corresponds to the size of pro-IL-18 (Fig. $1 B$ ). In control animals, IL-18 protein was expressed constitutively and no changes were observed at the different postnatal ages (Fig. 1C). At $1 \mathrm{~d}$ of reperfusion, a $50 \%$ increase in IL-18 protein was observed in the ipsilateral hemisphere ( $p=0.029$ vs contralateral hemisphere) (Fig. 1C). Similar to the mRNA levels, IL-18 protein expression was increased in the ipsilateral hemisphere at $3 \mathrm{~d}(p=0.05), 6 \mathrm{~d}$ $(p=0.0039)$ and $14 \mathrm{~d}(p=0.0039)$ of reperfusion, reaching a fivefold increase at $14 \mathrm{~d}$ compared with control pups (Fig. 1C).

To investigate whether there was active IL-18 present in the wild-type mice and whether the active form was upregulated after HI, IL-18 was also analyzed with an ELISA based on two monoclonal antibodies directed against two different epitopes of the mature (active) form of the protein. At P12, active IL-18 was present in both hemispheres at a concentration of $\sim 40 \mathrm{pg} / \mathrm{mg}$ total protein, which corresponded to the levels in the contralateral hemispheres after HI (Fig. 1D). The amount of active IL-18 was increased by $70 \%(p<0.001)$ in the ipsilateral hemisphere compared with the contralateral hemisphere at $3 \mathrm{~d}$ after $\mathrm{HI}$ and by $36 \%(p=0.013)$ at $6 \mathrm{~d}$ after HI (Fig. $1 D)$.

In sections from brain tissue, IL-18 protein was expressed in control animals by cells scattered throughout the hemispheres (data not shown). After HI, an increase in IL-18 immunoreactivity occurred at $\sim 12 \mathrm{hr}$ of reperfusion in the ipsilateral hemispheres. IL-18 immunoreactivity continued to increase in the ipsilateral hemisphere and at $24-72 \mathrm{hr}$ after $\mathrm{HI}$, and positive cells were found throughout the entire hemisphere (see Fig. $4 E$ ). At 6 and $14 \mathrm{~d}$ after HI, IL-18 immunoreactivity was strictly located in the areas of injury in the cortex and thalamus of the ipsilateral hemisphere (see Fig. $4 F$ ). No changes in immunoreactivity were observed in the contralateral hemispheres at any time point after HI. Preabsorption of the IL-18 antibody with $10 \times$ excess of IL-18 blocking peptide prevented all immunoreactivity (data not shown). All cells expressing IL-18 were identified as microglia by double-labeling immunofluorescence (see Fig. $5 D-F$ ) and were shown to be colocalized with caspase-1-positive cells (see Fig. $5 J-L)$.

\section{Cellular localization of the IL-18R}

In tissue sections, IL-18R immunoreactivity was found primarily in neurons (see Figs. $4 K, L, 5 P-R$ ) but also in a variety of other cell types (see Fig. 4N,O). However, the IL-18R was not expressed by all neurons. The IL-18R-positive cells were located in both the cortex and the thalamus at all time points after $\mathrm{HI}$, and no distinct differences in IL-18R expression were found at different time points after HI or between hemispheres.

\section{Caspase-1 mRNA and protein expression after $\mathrm{HI}$}

To determine whether the expression of caspase- 1 was altered after HI, RT-PCR was performed on mRNA isolated from ipsilateral and contralateral hemispheres at several time points after HI and from control brains. The RT-PCR produced a single 339 bp caspase-1 fragment of the expected size (data not shown). Unoperated control animals showed no differences in caspase-1 mRNA expression between hemispheres or during normal development (P7, P8, P10, P13, and P21) (Fig. 2A). Individual samples
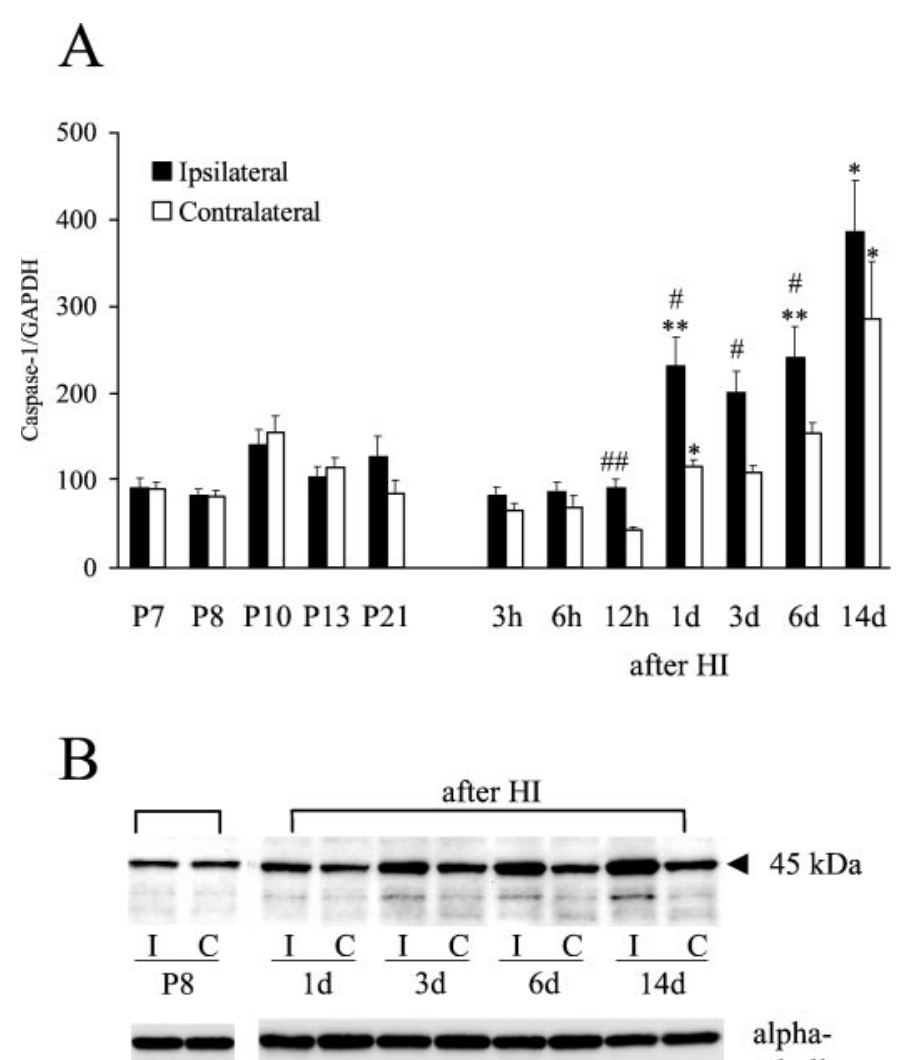

tubulin

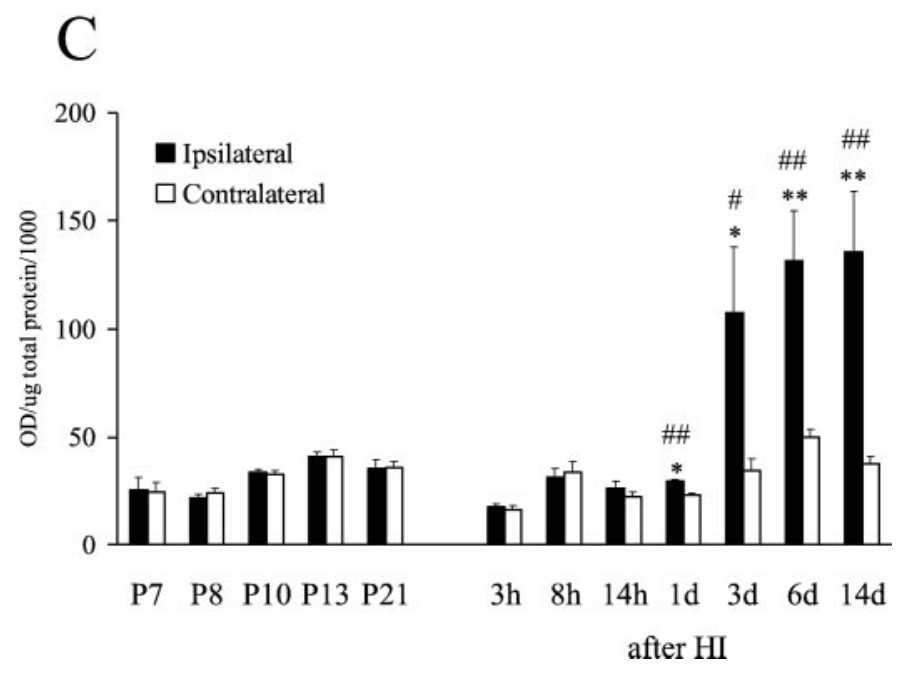

Figure 2. Upregulation of caspase-1 mRNA $(A)$ and protein $(B, C)$ levels after HI. Caspase-1 mRNA levels were normalized against GAPDH mRNA, and the results in $A$ are shown as the ratio of caspase-1/GAPDH. $B$, Results from some individual samples are shown; a $45 \mathrm{kDa}$ band and an apparent $35 \mathrm{kDa}$ breakdown product of caspase- 1 were detected. $\alpha$-Tubulin was used as control for equal loading. $I$ and $C$ indicate the ipsilateral and contralateral hemispheres, respectively, of the same animal at each time point. Western blots are shown for control animals at P8 and at various times of recovery after $\mathrm{HI}(1,3,6$, and $14 \mathrm{~d})$. C, Expression of the $45 \mathrm{kDa}$ caspase- 1 protein from measured values. $O D$, Optical density. In $A$ and $C$, results are given for control animals at different postnatal ages (P7, P8, P10, P13, and P21) and at different time points of recovery after $\mathrm{HI}\left(n=6\right.$ in each group). Data are expressed as mean $\pm \mathrm{SEM} ;{ }^{*} p<0.05$; $* * p<0.01$ when compared with the corresponding hemispheres from control animals of the same postnatal day. ${ }^{\#} p<0.05 ;{ }^{\# \#} p<0.01$ when compared with the contralateral hypoxic, undamaged hemispheres. 
( $n=6$ at each time point) showed a significant 2.8-fold increase in caspase-1 mRNA expression in the ipsilateral hemisphere $1 \mathrm{~d}$ after HI $(p=0.0065)$ when compared with control animals, and the expression continued to increase at $6 \mathrm{~d}(p=0.0039)$ and $14 \mathrm{~d}$ $(p=0.011$ ) of reperfusion (Fig. 2A). An upregulation of caspase-1 mRNA was also observed in the contralateral hypoxic hemisphere, but the caspase-1 mRNA levels were significantly higher in the ipsilateral compared with the contralateral hemispheres at $12 \mathrm{hr}$ to $6 \mathrm{~d}$ of reperfusion (Fig. $2 A$ ). The housekeeping gene GAPDH, which produced a 528 bp PCR fragment, was used for normalization. No changes in the mRNA levels of GAPDH were found after HI (data not shown).

The antibody against caspase- 1 displayed a distinct band on Western blots with an apparent molecular mass of $45 \mathrm{kDa}$, which corresponds to the proform of caspase-1 (Fig. 2B). Control animals expressed caspase- 1 protein constitutively, with no significant changes during normal development (Fig. $2 C)(n=6$ at each time point). A small (35\%) but significant increase in the $45 \mathrm{kDa}$ band was observed $1 \mathrm{~d}$ after $\mathrm{HI}$ in the ipsilateral hemisphere $(p=$ $0.01)$ when compared with the corresponding control animals (Fig. 2C). At $3 \mathrm{~d}$ after HI, a threefold increase in the expression of caspase-1 was observed in the ipsilateral hemisphere compared with control brains $(p=0.025)$. The expression of the $45 \mathrm{kDa}$ band continued to increase at $6 \mathrm{~d}(p=0.0039)$ and $14 \mathrm{~d}(p=$ 0.0039 ) of reperfusion (Fig. 2C). No significant increase in caspase-1 protein expression was observed in the contralateral hemispheres at any time point after HI. In tissue sections, the immunoreactivity in control animals was found in cells scattered throughout the brain. At $8 \mathrm{hr}$ after $\mathrm{HI}$, an increase in caspase-1 immunoreactivity was found in the habenular nucleus of the thalamus of the ipsilateral hemisphere, with no changes in the contralateral hemisphere (data not shown). Caspase-1 immunoreactivity continued to increase in the ipsilateral hemisphere after $\mathrm{HI}$, and the increase was similar in time and distribution to the observed increase in IL-18 immunoreactivity (see Fig. $4 A-F$ ). No changes in immunoreactivity were observed in the contralateral hemispheres at any time point after HI. Double-labeling immunofluorescence identified all caspase-1 immunoreactive cells as microglia (see Fig. $5 A-C)$. Preabsorption with $10 \times$ excess of the peptide for caspase-1 omitted all immunoreactivity.

\section{IL-1 $\beta$ protein expression after HI}

Control animals showed low expression of IL- $1 \beta$ protein with no differences during normal development (Fig. 3). After HI, the expression of IL- $1 \beta$ increased, exhibiting a biphasic pattern. The first and maximal increase occurred in the ipsilateral hemisphere at $8 \mathrm{hr}$ of reperfusion, attaining a 7.4-fold increase $(p=0.0066)$ compared with IL-1 $\beta$ in the contralateral hemisphere (Fig. 3). The levels of IL- $1 \beta$ protein in the ipsilateral hemisphere decreased gradually from $14 \mathrm{hr}$ (3.5-fold increase) to $72 \mathrm{hr}$ (twofold increase) after $\mathrm{HI}$; however, they were still significantly increased when compared with levels in contralateral hemispheres. At 6 and $14 \mathrm{~d}$ after $\mathrm{HI}$, a second (4.5-fold) increase in IL- $1 \beta$ protein was observed in the ipsilateral compared with the contralateral hemisphere (Fig. 3).

In tissue sections, changes in IL- $1 \beta$ protein expression followed those demonstrated by ELISA. At $8 \mathrm{hr}$ after $\mathrm{HI}$, an increase in IL- $1 \beta$-expressing cells was observed primarily in the habenular nucleus of the thalamus of the ipsilateral hemisphere (Fig. 4G), with no changes in immunoreactivity in the contralateral hemisphere. Double-labeling with immunofluorescence identified the

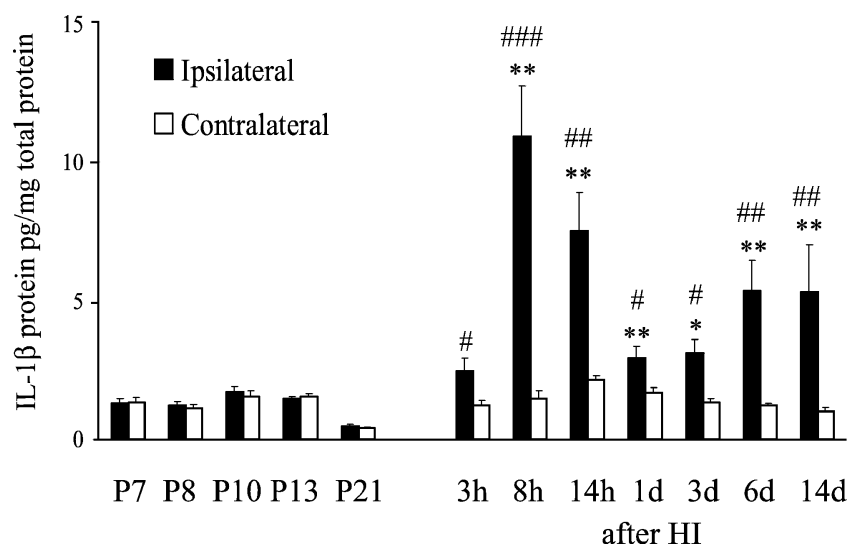

Figure 3. Changes in IL-1 $\beta$ protein expression (mean \pm SEM) after HI in the HI (ipsilateral) and contralateral hemispheres, as measured by ELISA. Results are given for control animals at different postnatal ages (P7, P8, P10, P13, and P21) and at different time points of recovery after HI ( $n=6$ in each group). ${ }^{*} p<0.05 ;{ }^{*} p<<0.01$ versus control animals of the same postnatal day. ${ }^{\#} p<0.05$; ${ }^{\# \#} p<0.01$; ${ }^{\# \# \#} p<0.001$ versus hypoxic but not ischemic contralateral hemispheres.

cells as microglia (Fig. 5G,I). IL-1 $\beta$-expressing microglia were still detected in the habenular nucleus of the ipsilateral hemisphere $12 \mathrm{hr}$ after $\mathrm{HI}$, but at $24 \mathrm{hr}$, no more immunoreactive cells were found in this region. However, some immunoreactivity was found in astrocytic processes in the cortex of the ipsilateral hemisphere. At 6 and 14 d after HI, a few IL- $1 \beta$-expressing microglia were observed in the injured regions of the ipsilateral hemisphere. Tissue sections from control animals showed no IL-1 $\beta$ immunoreactivity at any time point. Immunofluorescent double-labeling showed colocalization of IL- $1 \beta$-positive cells with caspase-1 (Fig. 5M-O). Preabsorption of the IL- $1 \beta$ antibody with $50 \times$ excess of recombinant IL- $1 \beta$ resulted in complete loss of immunoreactivity.

\section{Brain injury in IL-18 KO and wild-type mice}

Mortality or pup weight did not differ between IL-18-deficient and wild-type mice, which agrees with previous reports that IL-18-deficient mice develop normally and have a normal phenotype (Takeda et al., 1998). IL-18 was expressed in wild-type mice to a similar extent as observed in neonatal rats (Fig. $4 H$ ), whereas IL-18 was not expressed in IL-18 KO mice (Fig. 4M). There was no change in IL-1 $\beta$ protein expression after $\mathrm{HI}$ in IL-18 KO mice compared with wild-type mice (Fig. 4H,I). The extent and distribution of brain injury in wild-type mice was similar to that seen in neonatal rats. In most wild-type and IL-18-deficient animals, brain infarction/selective neuronal loss was observed in the cerebral cortex, hippocampus, striatum, and thalamus ipsilateral to the carotid artery occlusion. The area of infarction, measured as lack of MAP-2 immunoreactivity, was significantly reduced at 9 of 10 brain levels in IL-18 KO compared with wild-type mice (Fig. 6 A). The total volume of infarction, expressed as a percentage of the contralateral hemisphere, was reduced from $53 \pm 2.7 \%$ in wildtype mice to $42 \% \pm 2.7$ in IL-18-deficient mice (i.e., by $21 \%$ ) $(p=0.01)$. The neuropathological score was significantly lower in IL-18 KO mice than in wild-type mice for all regions evaluated (Fig. $6 B$ ), being most marked in the cerebral cortex $(-35 \%)$. The total score was significantly $(p<0.001)$ reduced in the IL-18 KO mice $(13.4 \pm 0.6)$ compared with wild-type mice $(17.2 \pm 0.5)$, and the total score for each animal is shown in Figure $6 C$. 


\section{caspase-1}
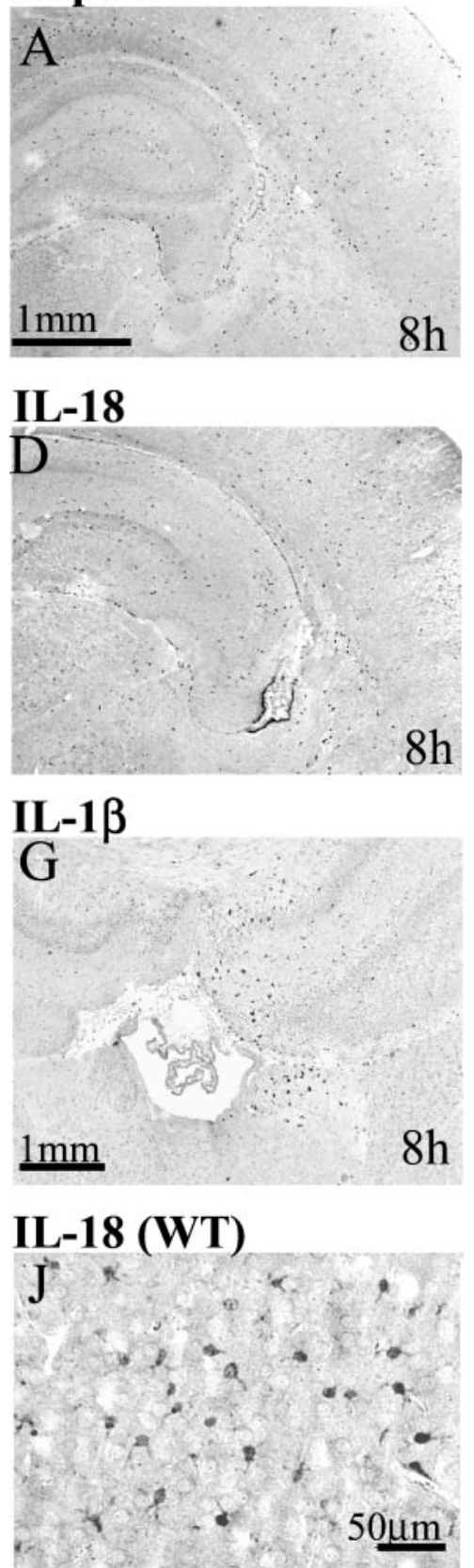

\section{IL-18 (IL-18 KO) $\mathrm{M}$}
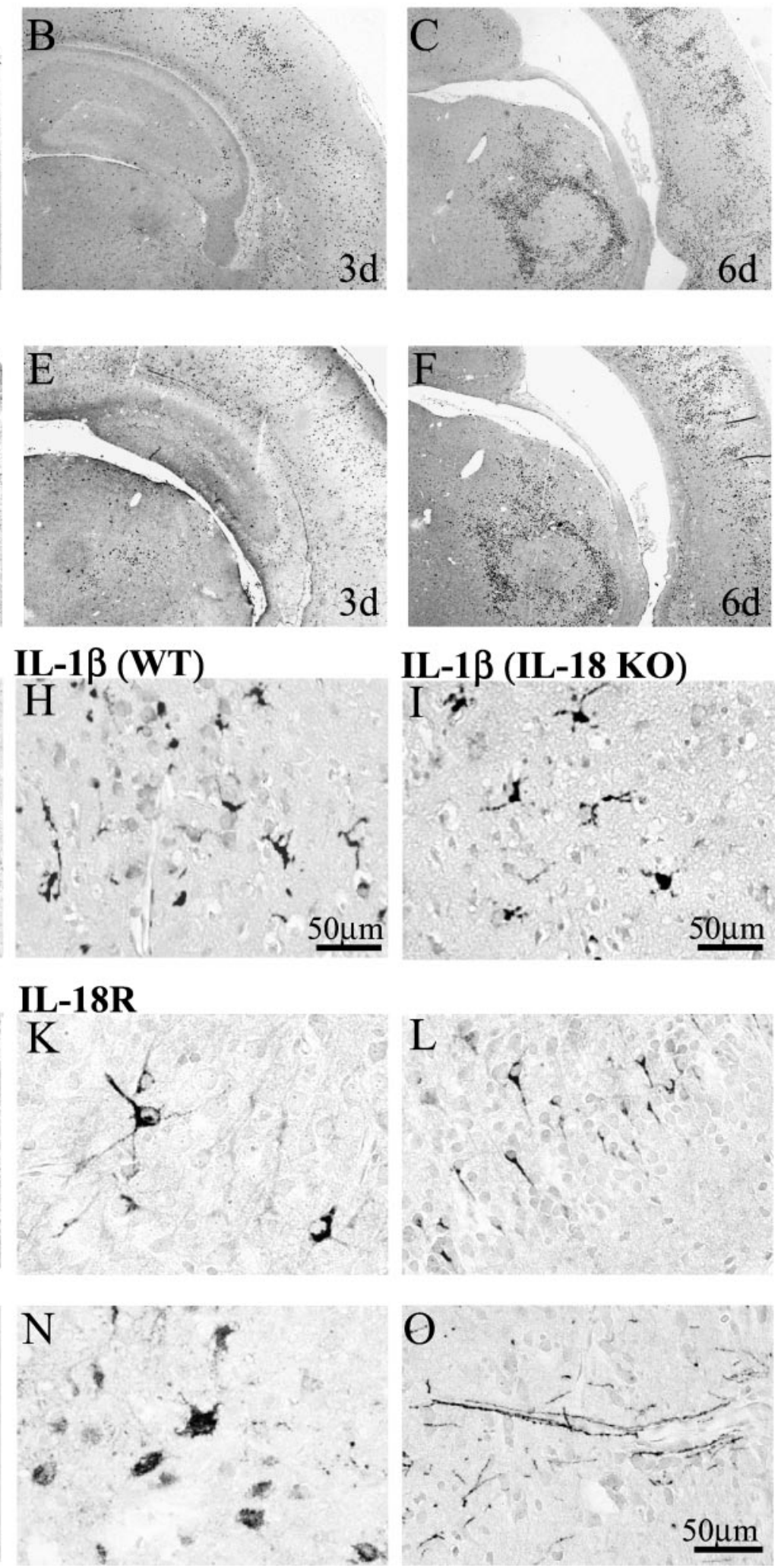

Figure 4. Cellular localization and distribution of caspase-1 $(A-C)$, IL-18 $(D-F)$, and IL-1 $\beta(G)$ immunoreactivity after HI in the ipsilateral (HI) hemisphere. The immunoexpression of IL-1 $\beta$ and IL-18 in IL-18 wild-type (WT) $(H, J)$ and IL-18-deficient (IL-18 KO) (I, $M)$ mice and of IL-18R (K, $L, N, O)$ are also presented. Caspase-1- and IL-18-positive cells displayed a very similar temporal and spatial distribution pattern after HI, as shown in $A-F$, at $8 \mathrm{hr}, 3 \mathrm{~d}$, and $6 \mathrm{~d}$ of reperfusion. IL- $1 \beta$-positive cells were strictly localized to and around the region of the nucleus habenularis at 8 hr after HI $(G)$, when maximal expression of IL- $1 \beta$ protein was present. IL-1 $\beta$ protein is expressed to a similar extent in wild-type $(H)$ and IL-18 KO $(I)$ mice $12 \mathrm{hr}$ after $\mathrm{HI}$ in the ipsilateral thalamus. IL-18 immunoreactivity was found in microglia in C57BL/6 wild-type $(J)$ but not IL-18 KO $(M)$ mice $3 \mathrm{~d}$ after HI. The expression of the IL-18R was found on neurons $(K, L)$ and on cells $(N)$ and processes $(O)$ not yet identified. 

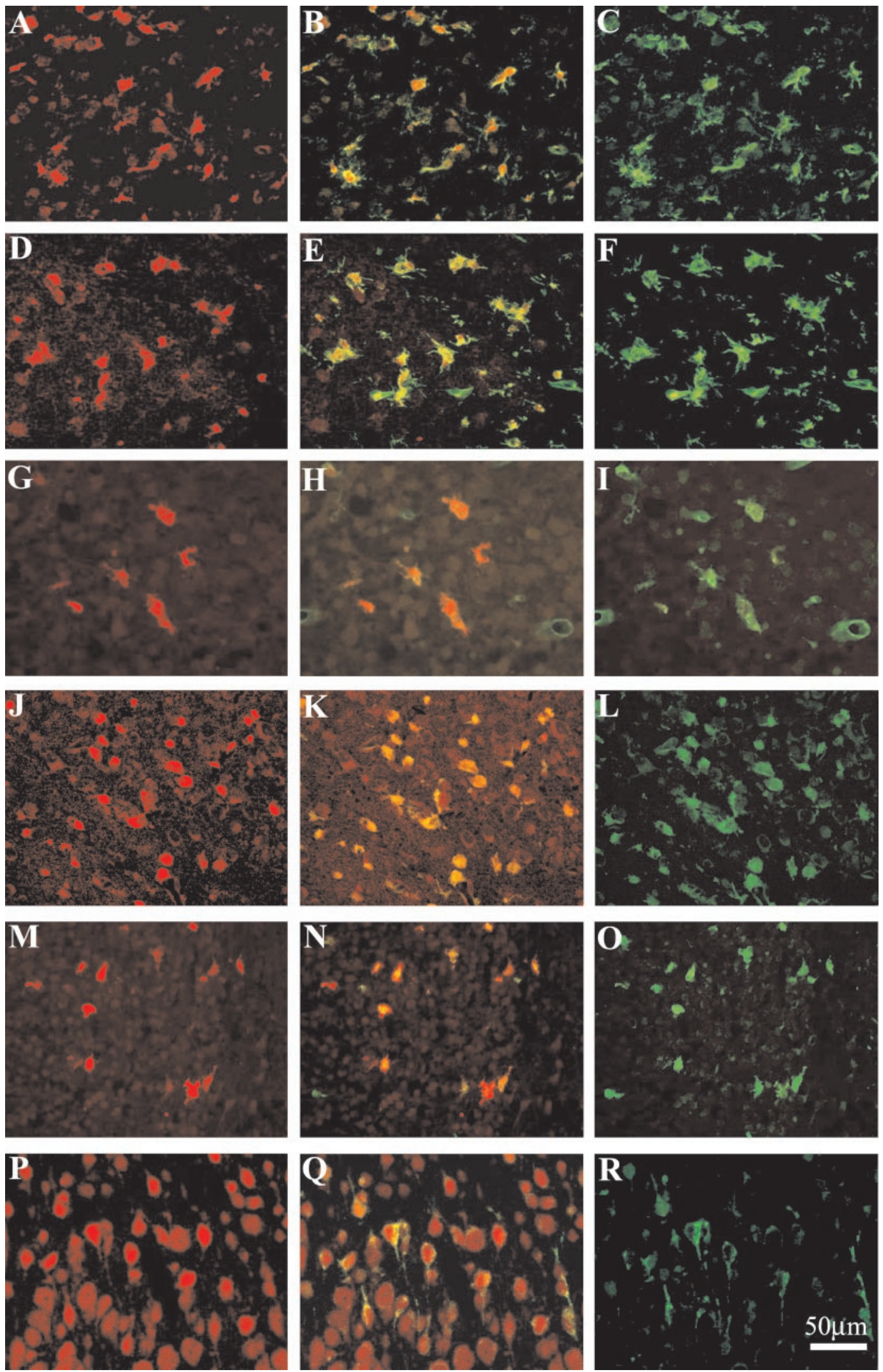

Figure 5. Double-labeling immunofluorescence experiments compared the immunoreactivity of caspase-1 $(A)$, IL-18 $(D)$ (thalamus region of ipsilateral hemisphere), and IL-1 $\beta(G)$ (habenular nucleus of ipsilateral hemisphere) with that of microglia stained with the isolectin antibody $(C, F, I)$. Caspase-1, IL-18 (thalamus region of ipsilateral hemisphere), and IL-1 $\beta$ (habenular nucleus of ipsilateral hemisphere) all colocalized with the microglial marker isolectin $(B, E$, and $H$, respectively). Furthermore, caspase-1 $(L, O)$ colocalized with its substrates IL-18 $(J)$ (thalamus region of ipsilateral hemisphere) and IL-1 $\beta(M)$ (habenular nucleus of ipsilateral hemisphere), respectively, as demonstrated in the overlay photographs shown in $K$ and $N$. The bottom row demonstrates colocalization $(Q)$ of neurons (stained with NeuN) $(P)$ with the IL-18R $(R)$ (cortex of ipsilateral hemisphere). 
A

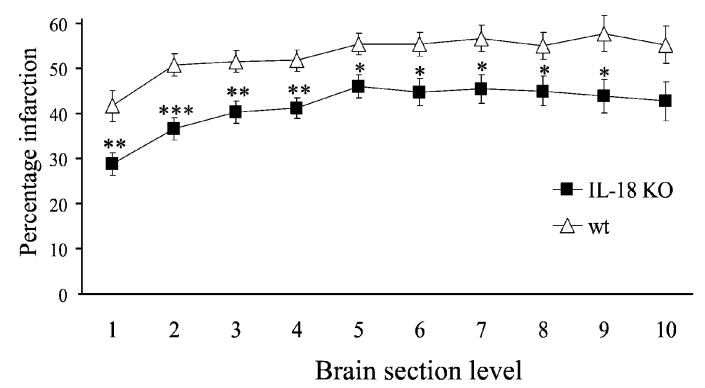

B

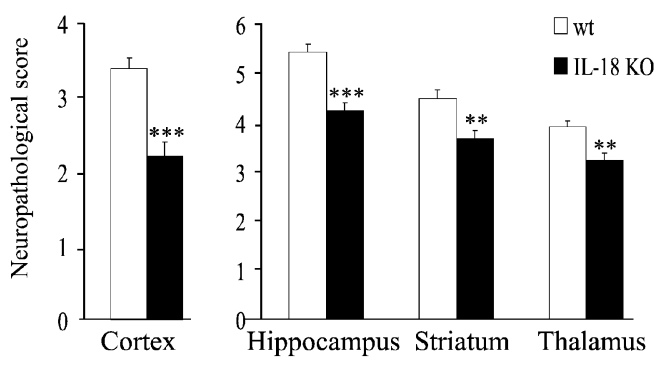

\section{$\mathrm{C}$}

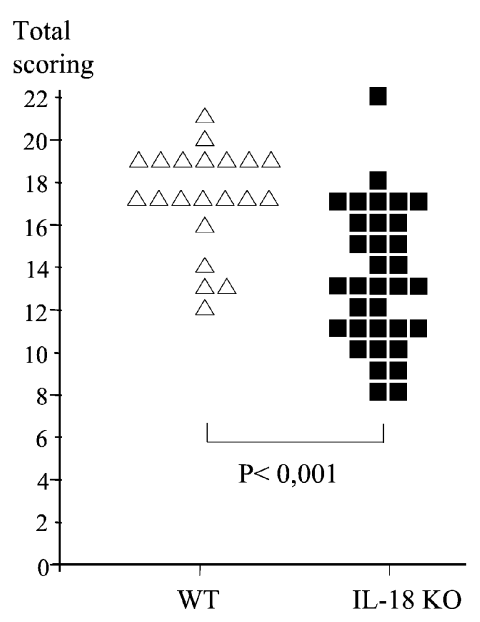

Figure 6. Reduction of brain injury in IL-18 KO mice compared with wild-type mice $(w t)$. $A$, Infarction size was quantified in 10 coronal sections numbered from anterior to posterior levels. Infarction was expressed as loss of MAP-2 immunoreactivity in the ipsilateral hemisphere as a percentage of the contralateral hemisphere. Values are given as mean \pm SEM. $* * * p<0.001 ; * *<<0.01 ; * p \leq 0.05$ versus wild type. $B$, Neuropathological scoring of HI brain injury in the cerebral cortex (0-4), hippocampus $(0-6)$, striatum $(0-6)$, and thalamus $(0-6)$ is shown. Values are given as mean \pm SEM. ${ }^{* *} p<0.001 ; * * p<0.01$ versus wild type. $C$, The total injury score $(0-22)$ for each animal is shown.

\section{DISCUSSION}

IL-18 has been shown to be upregulated after ischemia/reperfusion in the kidney (Daemen et al., 1999) and heart (Pomerantz et al., 2001), but there are no studies published addressing IL-18 involvement in brain injury. After HI, we found a distinct upregulation of caspase- 1 in microglia/macrophages that was colo- calized with its substrates IL-18 and IL-1 $\beta$. In addition, brain injury was attenuated in IL-18-deficient mice, suggesting that this cytokine participates in the inflammatory microglia-related response, which seems to increase brain injury after HI (McRae et al., 1995; Yrjanheikki et al., 1999; Galasso et al., 2000). Such an assumption is supported by a recent study demonstrating that IL-18 binding protein provides protection in a model of myocardial ischemia (Pomerantz et al., 2001).

The gradual increase in caspase- 1 (mRNA and protein) that was found is consistent with the findings in brains from adult gerbils after ischemia, in which increased levels of caspase-1 mRNA as well as protein were observed, starting at $24 \mathrm{hr}$ after insult and increasing over time with the highest levels found at the latest investigated time point (14 d after injury) (Bhat et al., 1996). IL-18 mRNA has been detected previously in brain tissue (Culhane et al., 1998; Wildbaum et al., 1998), but the expression after ischemia has not been addressed. Similar to caspase-1 changes after HI, we found an increase in IL-18 mRNA and protein levels in the injured hemisphere 1-14 d after injury, with the most marked increase at $14 \mathrm{~d}$. In contrast, the maximal increase in IL- $1 \beta$ protein occurred $8 \mathrm{hr}$ after $\mathrm{HI}$, earlier than the peak in caspase- 1 and IL-18 protein expression, and then a secondary rise occurred $6-14 \mathrm{~d}$ after HI. IL- $1 \beta$ protein was detected almost exclusively in and around the region of the habenular nucleus of the injured hemisphere, where it was colocalized with caspase- 1 in microglia, but only a few of all caspase1-positive cells also expressed IL- $1 \beta$, even at the time point of maximal IL-1 $\beta$ expression. Expression of IL-18 and caspase-1, in contrast, showed a close correlation in time and distribution, and virtually all caspase-1-positive cells were also IL-18 positive. Hence, we report a rather low expression of IL- $1 \beta$ after HI and a poor correlation between caspase- 1 and IL- $1 \beta$ compared with the correlation between caspase- 1 and IL-18 expression. It has also been demonstrated that IL-18 is actually the preferred substrate for caspase-1 (Rano et al., 1997). This indicates that IL-18 might, in addition to IL-1 $\beta$, have an essential function in the pathway of events leading to brain injury after HI, which was supported by the relative resistance of IL-18-deficient animals to HI brain injury. The time course for development of brain injury in this model depends on the severity (duration) of the HI insult. In the present study, a moderate insult was induced, which results in somewhat delayed development of injury over at least 1-2 d (Blumberg et al., 1997; Gilland et al., 1998; Nakajima et al., 2000). Hence, IL-18 expression, which was increased $12 \mathrm{hr}$ to $14 \mathrm{~d}$ after HI, most likely occurred within the time frame for development of brain injury.

The critical role of IL- $1 \beta$ in brain injury is well established (Relton and Rothwell, 1992; Loddick and Rothwell, 1996), and it is important to consider its possible interaction with IL-18. The expression of IL- $1 \beta$ was not upregulated or downregulated in IL-18-deficient mice, which suggests that the reduction of injury in the IL-18 KO mice was not directly related to IL- $1 \beta$. However, these two cytokines do share many properties, and IL-18 may be expected to potentiate the proinflammatory effects of IL- $1 \beta$. IL-18 induces production of IL- $1 \beta$ [and tumor necrosis factor- $\alpha$ (TNF- $\alpha$ ) ] in some cells (Puren et al., 1998), and both these cytokines recruit the Myd88-IL-1 receptor-associated kinaseTNF receptor-associated factor 6 second messenger sequence, resulting in nuclear factor $\kappa \mathrm{B}(\mathrm{NF} \kappa \mathrm{B})$ production with induction of proinflammatory genes, including that for inducible nitric oxide synthase (iNOS) (Lebel-Binay et al., 2000). Hence, iNOS aggravates injury in the immature brain (Ikeno et al., 2000), and 
activation of $\mathrm{NF} \kappa \mathrm{B}$ seems to aggravate injury after ischemia (Schneider et al., 1999). Furthermore, IL-18 and IL-1 $\beta$ both induce the expression of chemokines such as IL-8, which has chemoattractant properties on polymorphonuclear cells, and of macrophage inflammatory protein $1-\alpha$ and monocyte chemotactic protein-1 (Lebel-Binay et al., 2000), which are involved in the recruitment of monocytes, $\mathrm{T}$ cells, and eosinophils. Data have been published previously that suggest that the chemokine system is activated in the immature brain after HI (Bona et al., 1999) and might be involved in the development of injury (Galasso et al., 2000). Another important function of IL-18 is to induce production of T helper 1 (Th1) cytokines (IL-2 and IFN- $\gamma$ ), which it does in synergy with IL-12. When stimulated with IL-18 and IL-12, not only Th1 cells but also natural killer (NK) cells, activated B cells, and macrophages/microglia are potent IFN- $\gamma$ producers (Lebel-Binay et al., 2000). In addition to the proinflammatory functions of IL-18, the cytokine is also able to enhance cell-mediated immune cytotoxicity. IL-18 enhances the cytotoxic activity of immune cells by upregulating the expression of Fas ligand on NK and Th1 cells (Dao et al., 1996; Tsutsui et al., 1996) and by enhancing the perforin-mediated cytotoxic activity of NK cells (Hyodo et al., 1999). IL-18 could be involved in brain injury either indirectly, by causing an inflammatory reaction in the brain, or directly, through the enhancement of cytotoxic activity of immune cells. However, the infiltration of lymphocytes and NK cells into the brain tissue after HI is limited (Bona et al., 1999), and the participation of such cells is uncertain. Interestingly, we could report the expression of IL-18R on neurons. This suggests that IL-18 may have direct yet unknown functions on neurons. Recent data imply that IL-18 is expressed by brain microglia in response to viral challenge, which induces expression of IFN- $\gamma$ in neurons that in turn activates microglia. This microglia-neuronal interaction leads to apoptotic death of viruscontaining neurons and engulfment by microglia/macrophages and then to prompt inactivation of the IL-18 response (Mori et al., 2001). A similar sequence of events may occur after HI, but the IL-18 expression was nearly maximal even $14 \mathrm{~d}$ after insult, implicating a persistent rather than a transient inflammatory microglial response, which agrees with previous reports (McRae et al., 1995; Bona et al., 1999).

We found expression of caspase- 1 protein only in microglia. Our findings are consistent with the study in adult gerbils, in which the increase in caspase- 1 expression after ischemia was selectively localized in microglia (Bhat et al., 1996). The substrates IL-18 and IL- $1 \beta$ were also expressed by microglia, and they were colocalized with caspase- 1 . We found what appeared to be a $35 \mathrm{kDa}$ cleavage fragment, although we could not identify the p10 subunit of the active form complex with Western blotting. There are several possible reasons why the p10 subunit was not detected. The concentration may not have been high enough when analyzing the entire hemisphere, the half-life of the p10 subunit may have been too short to allow detection on Western blots, or the affinity of the antibody may have been too low. For example, in the case of caspase-3, the active p17 subunit was not always detectable by Western blot, even when the DEVDase activity was significantly increased (Blomgren et al., 2001). In adult gerbils, using the same antibody against caspase-1, no p10 subunit was detected after ischemia (Bhat et al., 1996). However, we have demonstrated previously that bioactive IL- $1 \beta$ was increased after HI using the same model (Hagberg et al., 1996), and presently we found detectable levels of active IL-18, as judged by the ELISA specific for the active form, strongly indicating that caspase- 1 was activated during reperfusion.

The detection of caspase- 1 activity after ischemia is controversial. According to some reports, no increase in caspase- 1 activity was detected after brain injury in neonatal or adult brain using activity assays (Yakovlev et al., 1997; Cheng et al., 1998). However, intracerebroventricular administration of a selective caspase-1 inhibitor (Ac-YVAD-cmk) has been shown to reduce brain injury in several in vivo models of ischemic (Hara et al., 1997; Rabuffetti et al., 2000) and traumatic (Fink et al., 1999) brain injury. The importance of caspase- 1 as a mediator of brain damage is also shown by the use of mice deficient in the gene for caspase-1. In both neonatal and adult animals, the lack of caspase-1 is protective against ischemia (Schielke et al., 1998; Liu et al., 1999). Caspase-1 knock-out mice do not release mature IL- $1 \beta$ or IL-18 (Wang and Lenardo, 2000). At present, IL-1 $\beta$ and IL-18 are the only known substrates for caspase-1. Both caspase-1 and its substrates are expressed by microglia, which are thought to play an important role in inflammatory and injurious processes in the brain after ischemic insults (Yrjanheikki et al., 1999).

In summary, we demonstrate that caspase- 1 and its two substrates, IL- $1 \beta$ and IL-18, were upregulated after HI in the immature brain. In addition, the spatial and temporal expression patterns of caspase- 1 and IL-18 were similar. We also report the expression of IL-18R on neurons, and that brain injury after HI was attenuated in IL-18 gene-disrupted mice compared with wild-type mice, suggesting a role for IL-18 in the pathophysiology of cellular injury in the immature brain.

\section{REFERENCES}

Bhat RV, DiRocco R, Marcy VR, Flood DG, Zhu Y, Dobrzanski P, Siman R, Scott R, Contreras PC, Miller M (1996) Increased expression of IL-1 $\beta$ converting enzyme in hippocampus after ischemia: selective localization in microglia. J Neurosci 16:4146-4154.

Blomgren K, Hallin U, Andersson AL, Puka-Sundvall M, Bahr BA, McRae A, Saido TC, Kawashima S, Hagberg H (1999) Calpastatin is up-regulated in response to hypoxia and is a suicide substrate to calpain after neonatal cerebral hypoxia-ischemia. J Biol Chem 274:14046-14052.

Blomgren K, Zhu C, Wang X, Karlsson JO, Leverin AL, Bahr BA, Mallard C, Hagberg H (2001) Synergistic activation of caspase-3 by m-calpain after neonatal hypoxia-ischemia: a mechanism of "pathological apoptosis"? J Biol Chem 276:10191-10198.

Blumberg RM, Cady EB, Wigglesworth JS, McKenzie JE, Edwards AD (1997) Relation between delayed impairment of cerebral energy metabolism and infarction following transient focal hypoxia-ischaemia in the developing brain. Exp Brain Res 113:130-137

Bona E, Hagberg H, Loberg EM, Bagenholm R, Thoresen M (1998) Protective effects of moderate hypothermia after neonatal hypoxiaischemia: short- and long-term outcome. Pediatr Res 43:738-745.

Bona E, Andersson AL, Blomgren K, Gilland E, Puka-Sundvall M, Gustafson K, Hagberg H (1999) Chemokine and inflammatory cell response to hypoxia-ischemia in immature rats. Pediatr Res 45:500-509.

Cheng Y, Deshmukh M, D'Costa A, Demaro JA, Gidday JM, Shah A, Sun Y, Jacquin MF, Johnson EM, Holtzman DM (1998) Caspase inhibitor affords neuroprotection with delayed administration in a rat model of neonatal hypoxic-ischemic brain injury. J Clin Invest 101:1992-1999.

Chirgwin JM, Przybyla AE, MacDonald RJ, Rutter WJ (1979) Isolation of biologically active ribonucleic acid from sources enriched in ribonuclease. Biochemistry 18:5294-5299.

Conti B, Park LC, Calingasan NY, Kim Y, Kim H, Bae Y, Gibson GE, Joh TH (1999) Cultures of astrocytes and microglia express interleukin 18. Brain Res Mol Brain Res 67:46-52.

Culhane AC, Hall MD, Rothwell NJ, Luheshi GN (1998) Cloning of rat brain interleukin-18 cDNA. Mol Psychiatry 3:362-366.

Daemen MA, van't Veer C, Wolfs TG, Buurman WA (1999) Ischemia/ reperfusion-induced IFN-gamma up-regulation: involvement of IL-12 and IL-18. J Immunol 162:5506-5510.

Dao T, Ohashi K, Kayano T, Kurimoto M, Okamura H (1996) Interferon-gamma-inducing factor, a novel cytokine, enhances Fas ligand-mediated cytotoxicity of murine T helper 1 cells. Cell Immunol 173:230-235. 
Dinarello CA (1999) Interleukin-18. Methods 19:121-132.

Fink KB, Andrews LJ, Butler WE, Ona VO, Li M, Bogdanov M, Endres M, Khan SQ, Namura S, Stieg PE, Beal MF, Moskowitz MA, Yuan J, Friedlander RM (1999) Reduction of post-traumatic brain injury and free radical production by inhibition of the caspase-1 cascade. Neuroscience 94:1213-1218.

Galasso JM, Liu Y, Szaflarski J, Warren JS, Silverstein FS (2000) Monocyte chemoattractant protein-1 is a mediator of acute excitotoxic injury in neonatal rat brain. Neuroscience 101:737-744.

Gilland E, Bona E, Hagberg H (1998) Temporal changes of regional glucose use, blood flow, and microtubule-associated protein 2 immunostaining after hypoxia-ischemia in the immature rat brain. J Cereb Blood Flow Metab 18:222-228.

Hagberg H, Gilland E, Bona E, Hanson LA, Hahn-Zoric M, Blennow M, Holst M, McRae A, Soder O (1996) Enhanced expression of interleukin (IL)-1 and IL-6 messenger RNA and bioactive protein after hypoxia-ischemia in neonatal rats. Pediatr Res 40:603-609.

Hara H, Friedlander RM, Gagliardini V, Ayata C, Fink K, Huang Z, Shimizu-Sasamata M, Yuan J, Moskowitz MA (1997) Inhibition of interleukin 1beta converting enzyme family proteases reduces ischemic and excitotoxic neuronal damage. Proc Natl Acad Sci USA 94:2007-2012.

Hyodo Y, Matsui K, Hayashi N, Tsutsui H, Kashiwamura S, Yamauchi H, Hiroishi K, Takeda K, Tagawa Y, Iwakura Y, Kayagaki N, Kurimoto M, Okamura H, Hada T, Yagita H, Akira S, Nakanishi K, Higashino K (1999) IL-18 up-regulates perforin-mediated NK activity without increasing perforin messenger RNA expression by binding to constitutively expressed IL-18 receptor. J Immunol 162:1662-1668.

Ikeno S, Nagata N, Yoshida S, Takahashi H, Kigawa J, Terakawa N (2000) Immature brain injury via peroxynitrite production induced by inducible nitric oxide synthase after hypoxia-ischemia in rats. J Obstet Gynaecol Res 26:227-234.

Lebel-Binay S, Berger A, Zinzindohoue F, Cugnenc P, Thiounn N, Fridman WH, Pages F (2000) Interleukin-18: biological properties and clinical implications. Eur Cytokine Netw 11:15-26.

Liu XH, Kwon D, Schielke GP, Yang GY, Silverstein FS, Barks JD (1999) Mice deficient in interleukin-1 converting enzyme are resistant to neonatal hypoxic-ischemic brain damage. J Cereb Blood Flow Metab 19:1099-1108.

Loddick SA, Rothwell NJ (1996) Neuroprotective effects of human recombinant interleukin-1 receptor antagonist in focal cerebral ischaemia in the rat. J Cereb Blood Flow Metab 16:932-940.

Mallard EC, Williams CE, Gunn AJ, Gunning MI, Gluckman PD (1993) Frequent episodes of brief ischemia sensitize the fetal sheep brain to neuronal loss and induce striatal injury. Pediatr Res 33:61-65.

Martin D, Chinookoswong N, Miller G (1994) The interleukin-1 receptor antagonist (rhIL-1ra) protects against cerebral infarction in a rat model of hypoxia-ischemia. Exp Neurol 130:362-367.

McRae A, Gilland E, Bona E, Hagberg H (1995) Microglia activation after neonatal hypoxic-ischemia. Brain Res Dev Brain Res 84:245-252.

Mori I, Hossain MJ, Takeda K, Okamura H, Imai Y, Kohsaka S, Kimura Y (2001) Impaired microglial activation in the brain of IL-18-genedisrupted mice after neurovirulent influenza A virus infection. Virology 287:163-170.

Nakajima W, Ishida A, Lange MS, Gabrielson KL, Wilson MA, Martin LJ, Blue ME, Johnston MV (2000) Apoptosis has a prolonged role in the neurodegeneration after hypoxic ischemia in the newborn rat. J Neurosci 20:7994-8004.

Okamura H, Tsutsui H, Komatsu T, Yutsudo M, Hakura A, Tanimoto T, Torigoe K, Okura T, Nukada Y, Hattori K, Akita K, Namba M, Tanabe F, Konishi K, Fukuda S, Kurimoto M (1995) Cloning of a new cytokine that induces IFN-gamma production by $\mathrm{T}$ cells. Nature 378:88-91.

Pomerantz BJ, Reznikov LL, Harken AH, Dinarello CA (2001) Inhibition of caspase 1 reduces human myocardial ischemic dysfunction via inhibition of IL-18 and IL-1beta. Proc Natl Acad Sci USA 98:2871-2876.

Prinz M, Hanisch UK (1999) Murine microglial cells produce and respond to interleukin-18. J Neurochem 72:2215-2218.
Puren AJ, Fantuzzi G, Gu Y, Su MS, Dinarello CA (1998) Interleukin-18 (IFNgamma-inducing factor) induces IL-8 and IL1beta via TNFalpha production from non-CD14+ human blood mononuclear cells. J Clin Invest 101:711-721.

Rabuffetti M, Sciorati C, Tarozzo G, Clementi E, Manfredi AA, Beltramo M (2000) Inhibition of caspase-1-like activity by Ac-Tyr-ValAla-Asp-chloromethyl ketone induces long-lasting neuroprotection in cerebral ischemia through apoptosis reduction and decrease of proinflammatory cytokines. J Neurosci 20:4398-4404.

Rano TA, Timkey T, Peterson EP, Rotonda J, Nicholson DW, Becker JW, Chapman KT, Thornberry NA (1997) A combinatorial approach for determining protease specificities: application to interleukin-1beta converting enzyme (ICE). Chem Biol 4:149-155.

Relton JK, Rothwell NJ (1992) Interleukin-1 receptor antagonist inhibits ischaemic and excitotoxic neuronal damage in the rat. Brain Res Bull 29:243-246.

Rice III JE, Vannucci RC, Brierley JB (1981) The influence of immaturity on hypoxic-ischemic brain damage in the rat. Ann Neurol 9:131-141.

Schielke GP, Yang GY, Shivers BD, Betz AL (1998) Reduced ischemic brain injury in interleukin-1 beta converting enzyme-deficient mice. J Cereb Blood Flow Metab 18:180-185.

Schneider A, Martin-Villalba A, Weih F, Vogel J, Wirth T, Schwaninger M (1999) NF-kappaB is activated and promotes cell death in focal cerebral ischemia. Nat Med 5:554-559.

Silverstein FS, Barks JD, Hagan P, Liu XH, Ivacko J, Szaflarski J (1997) Cytokines and perinatal brain injury. Neurochem Int 30:375-383.

Stroemer RP, Rothwell NJ (1997) Cortical protection by localized striatal injection of IL-1ra following cerebral ischemia in the rat. J Cereb Blood Flow Metab 17:597-604.

Stroemer RP, Rothwell NJ (1998) Exacerbation of ischemic brain damage by localized striatal injection of interleukin-1beta in the rat. J Cereb Blood Flow Metab 18:833-839.

Szaflarski J, Burtrum D, Silverstein FS (1995) Cerebral hypoxiaischemia stimulates cytokine gene expression in perinatal rats. Stroke 26:1093-1100.

Takeda K, Tsutsui H, Yoshimoto T, Adachi O, Yoshida N, Kishimoto T, Okamura H, Nakanishi K, Akira S (1998) Defective NK cell activity and Th1 response in IL-18-deficient mice. Immunity 8:383-390.

Tsutsui H, Nakanishi K, Matsui K, Higashino K, Okamura H, Miyazawa Y, Kaneda K (1996) IFN-gamma-inducing factor up-regulates Fas ligand-mediated cytotoxic activity of murine natural killer cell clones. J Immunol 157:3967-3973.

Wang J, Lenardo MJ (2000) Roles of caspases in apoptosis, development, and cytokine maturation revealed by homozygous gene deficiencies. J Cell Sci 113:753-757.

Whitaker JR, Granum PE (1980) An absolute method for protein determination based on difference in absorbance at 235 and $280 \mathrm{~nm}$. Anal Biochem 109:156-159.

Wildbaum G, Youssef S, Grabie N, Karin N (1998) Neutralizing antibodies to IFN-gamma-inducing factor prevent experimental autoimmune encephalomyelitis. J Immunol 161:6368-6374.

Yakovlev AG, Knoblach SM, Fan L, Fox GB, Goodnight R, Faden AI (1997) Activation of CPP32-like caspases contributes to neuronal apoptosis and neurological dysfunction after traumatic brain injury. J Neurosci 17:7415-7424.

Yamasaki Y, Matsuura N, Shozuhara H, Onodera H, Itoyama Y, Kogure K (1995) Interleukin-1 as a pathogenetic mediator of ischemic brain damage in rats. Stroke 26:676-681.

Yoon BH, Jun JK, Romero R, Park KH, Gomez R, Choi JH, Kim IO (1997) Amniotic fluid inflammatory cytokines (interleukin-6, interleukin-1beta, and tumor necrosis factor-alpha), neonatal brain white matter lesions, and cerebral palsy. Am J Obstet Gynecol 177:19-26.

Yrjanheikki J, Tikka T, Keinanen R, Goldsteins G, Chan PH, Koistinaho J (1999) A tetracycline derivative, minocycline, reduces inflammation and protects against focal cerebral ischemia with a wide therapeutic window. Proc Natl Acad Sci USA 96:13496-13500. 